\title{
Earthquake damage assessment: a theoretical framework and its application to Algerian buildings
}

\author{
M. Boukri ${ }^{1,2}$, M. N. Farsi ${ }^{1}$, A. Mébarki ${ }^{3}$ \& M. Belazougui ${ }^{1}$ \\ ${ }^{I}$ National Earthquake Engineering Research Centre, Algeria \\ ${ }^{2}$ Civil engineering department, Saad Dahlab University, Algeria \\ ${ }^{3}$ Laboratoire Modélisation et Simulation Multi Echelle, \\ Université Paris-Est, France
}

\begin{abstract}
Algeria is one of the countries that have experienced several moderate to strong earthquakes during the last three decades causing considerable damage in the urban areas. This damage can be reduced if we proceed to estimate the seismic risk in sufficient time in order to take adequate preventive measures. In this paper, an earthquake damage assessment methodology, adapted from HAZUS approach (Hazard-United States) to the Algerian building context, which relies on the capacity spectrum method, is presented. It aims to estimate the damages and potential losses that may be generated by a given earthquake in a prone area. This methodology was calibrated and validated using the data of observed damages for $\sim 3,700$ buildings in Boumerdès city in the aftermath of the May 21st 2003 earthquake $(\mathrm{Mw}=6.8)$. On the other hand, this methodology constitutes a decision-making tool for the concerned governmental organizations in charge to give the seismic warning with a level relative to the damage level, which can be estimated automatically by the data-processing code developed for this purpose, once the epicentre is localised and the magnitude known.

Keywords: Algeria, buildings, Hazus, vulnerability, fragility, capacity, damage, elastic spectrum, Boumerdès earthquake, Algerian seismic code.
\end{abstract}

\section{Introduction}

The historical seismicity, [1,2], shows that Algeria is one of the countries where the seismic activity is high. It knew several strong earthquakes during the three last decades. Since the El Asnam earthquake (October 10, 1980; Ms = 7.3), 
which caused more than 2600 deaths and destroyed or damaged more than 60,000 buildings, several moderate but destroying earthquakes occurred in Constantine (October 27, 1985; Ms = 5.7), Chenoua (October 29, 1989; Ms = 6.0), Mascara (August 8, 1994; Ms = 5.6), Algiers (September 4, 1996; $\mathrm{Ms}=5.6$ ), Ain Temouchent (December 22, 1999; Ms = 5.6) and Beni-Ourtilane (November 10, 2000; Ms $=5.5$ ). Recently, the region of Boumerdès (50 Km East of Algiers) was struck by a magnitude Mw 6.8 earthquake on May 21st, 2003 (Belazougui [3]), which caused considerable damage and almost 2300 deaths. The experience of these last earthquakes showed that the relief interventions have taken place only after the return of the first investigators, which may take a long time to give the information and therefore decreasesthe chance to find survivors. This delay is due to the non-fast localization of the affected zones and to the ignorance of the level of alarm to be given.

Just after a destroying earthquake, the catastrophe managers must take urgent decisions to mobilize the necessary means, according to the damages and their geographical distribution. This requires a preparation and installation of seismic risk reduction strategies in order to reduce the human and economic losses by the development of decision making tools.

The seismic damage estimation studies are a very useful tool to develop preparation and emergency management plans (Agrawal [4]). The risk assessment process began at the end of the 19th century, by the systematic recording of the weather, stream heights and then earthquakes (Charles [5]). The first to draw up the benefit of the risk reduction studies was John R. Freeman, in his work "Earthquake Damage and Earthquake Insurance", realised in 1932 [5], where it reviewed the catastrophes history. During the 1990's, the loss estimation models saw a significant and fast development (Clark [6]), following several storms in Europe, the Andrew hurricane in 1992, the Northridge earthquake (USA, 1994) and the Kobe earthquake (Japan, 1995), which caused catastrophic losses to the world insurers and reinsurers, who recognized the utility of such models. Indeed, these models allow a better quantification of the covered risks and thus a better knowledge of their exposure.

In this work, we elaborated an earthquake damage assessment methodology for Algerian buildings based on HAZUS approach whose capacity and fragility curves of related typologies were adapted to corresponding typologies of the Algerian building context.

\section{Earthquake damage assessment methodology for Algerian buildings}

The earthquake damage assessment process adopted (fig. 1) is based on HAZUS methodology (The FEMA Tool Estimating Earthquake Losses) [7], which relies on the capacity spectrum method developed from several scientific researches, [8-12]. The main parameters are the seismic solicitation represented by a response spectrum and the structure behaviour represented by its capacity curve. The performance point, which is the intersection between the capacity curve and the response spectrum, represents the behaviour of the building subjected to a 
given earthquake, fig. 1. It allows us to calculate the damage probability for each damage level according to its location on the fragility curves and therefore describes the damage level the considered structure under the given seismic input.
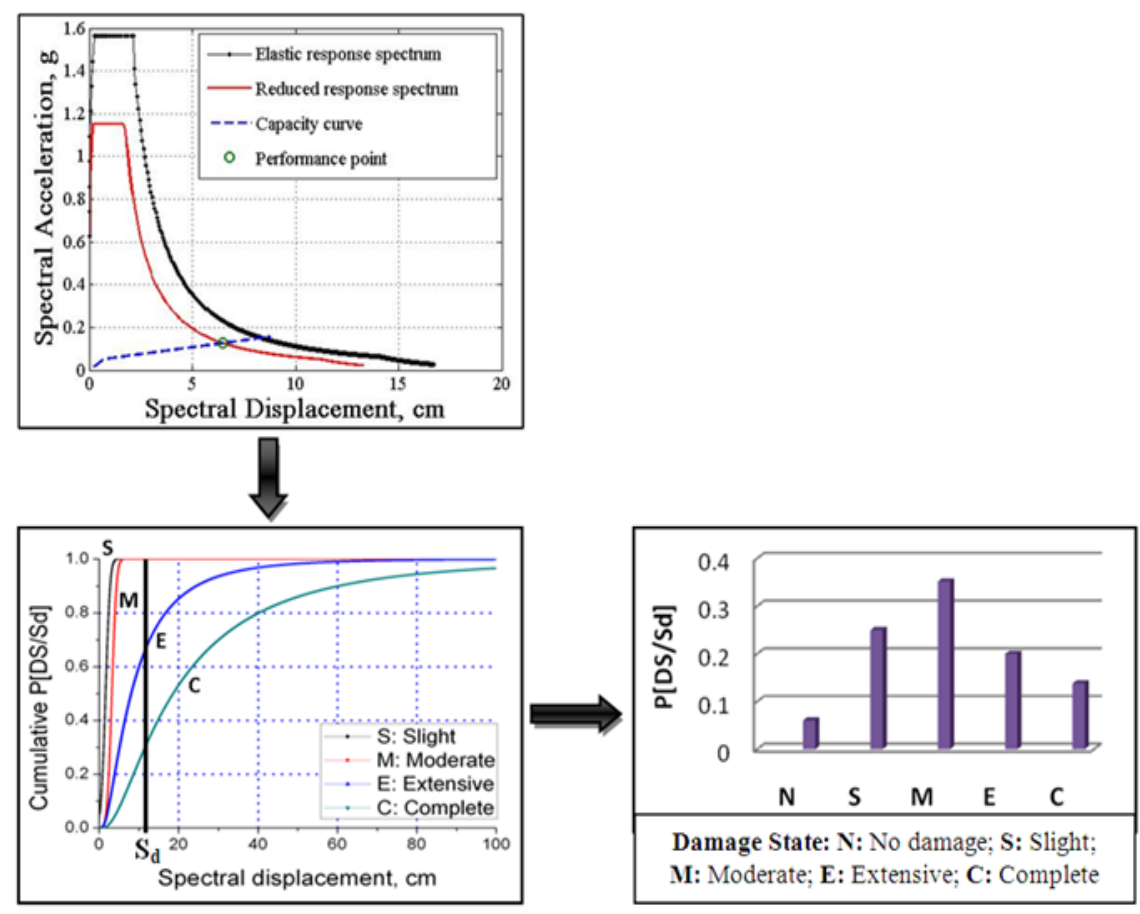

Figure 1: $\quad$ Earthquake damage estimation procedure.

\subsection{Building classification}

The building inventory and its classification constitute the main step for seismic damage assessment in an urban area. The selected building classification is based on the type of lateral-bracing, number of stories as well as the period of construction. We chose the constructions types defined in the Algerian seismic code (RPA99/Version 2003), most widespread in Algeria, This distinction is roughly homogeneous with the most existing classifications in the world earthquake loss estimation and particularly that used by the HAZUS methodology [7]. Thus, eleven standard building classes were analysed as illustrated in table 1. 
Table 1: Building typologies used for the methodology.

\begin{tabular}{|c|c|c|c|c|}
\hline \multirow{2}{*}{$\mathrm{N}^{\circ}$} & \multirow{2}{*}{ Typology } & \multirow{2}{*}{ Type of lateral-bracing } & \multicolumn{2}{|c|}{ Interval inter stories } \\
\hline & & & Name & Number \\
\hline 1 & RC1-B & \multirow{3}{*}{$\begin{array}{l}\text { Reinforced Concrete Beam- } \\
\text { Columns Structures }\end{array}$} & Low-rise & $1-3$ \\
\hline 2 & RC1-M & & Medium-rise & $4-7$ \\
\hline 3 & $\mathrm{RC} 1-\mathrm{H}$ & & High-rise & 8 and more \\
\hline 4 & RC2-B & \multirow{3}{*}{$\begin{array}{c}\text { Reinforced Concrete Shear } \\
\text { Walls Structures }\end{array}$} & Low-rise & $1-3$ \\
\hline 5 & RC2-M & & Medium-rise & $4-7$ \\
\hline 6 & $\mathrm{RC} 2-\mathrm{H}$ & & High-rise & 8 and more \\
\hline 7 & S-B & \multirow{3}{*}{ Steel Structures } & Low-rise & $1-3$ \\
\hline 8 & S-M & & Medium-rise & $4-7$ \\
\hline 9 & S-H & & High-rise & 8 and more \\
\hline 10 & URM-B & \multirow{2}{*}{$\begin{array}{c}\text { Unreinforced Masonry } \\
\text { Structures (Bearing walls) }\end{array}$} & Low-rise & $1-2$ \\
\hline 11 & URM-M & & Medium-rise & 3 and more \\
\hline
\end{tabular}

\subsection{Capacity and fragility curves}

In this study, we used capacity and fragility curves developed and used in the HAZUS methodology [7], which take account of the American seismic design level (high code, moderate code, low code and pre-code). This choice was made by taking into account the Algerian building context. Indeed, we used the capacity and fragility curves of the existing building types in Algeria, while trying to make closeness between the application levels of the American seismic code, UBC, [7], and the Algerian seismic code, RPA, in order to use these curves. Hence, we defined four seismic design levels according to evolution periods' of the various versions of the Algerian seismic building code bringing a change in the design level, as shown in table 2.

Table 2: $\quad$ Seismic design levels according to evolution periods of the Algerian seismic code (RPA).

\begin{tabular}{|c|c|c|c|c|}
\hline Code version & Post 2003 & 1999-2003 & 1981-1999 & Pre 1981 \\
\hline Code level & High-code & Moderate-code & Low-code & Pre-code \\
\hline
\end{tabular}

\section{Calibration of the methodology}

In order to test and calibrate the seismic loss estimation methodology elaborated for the Algerian buildings, we implemented it to the case of the Boumerdès urban area (located at $50 \mathrm{~km}$ East of Algiers city), fig. 2, which was stricken on May 21, 2003 by a destructive moment magnitude $6.8(\mathrm{Mw})$ earthquake (Boukri and Bensaïbi [13]). 


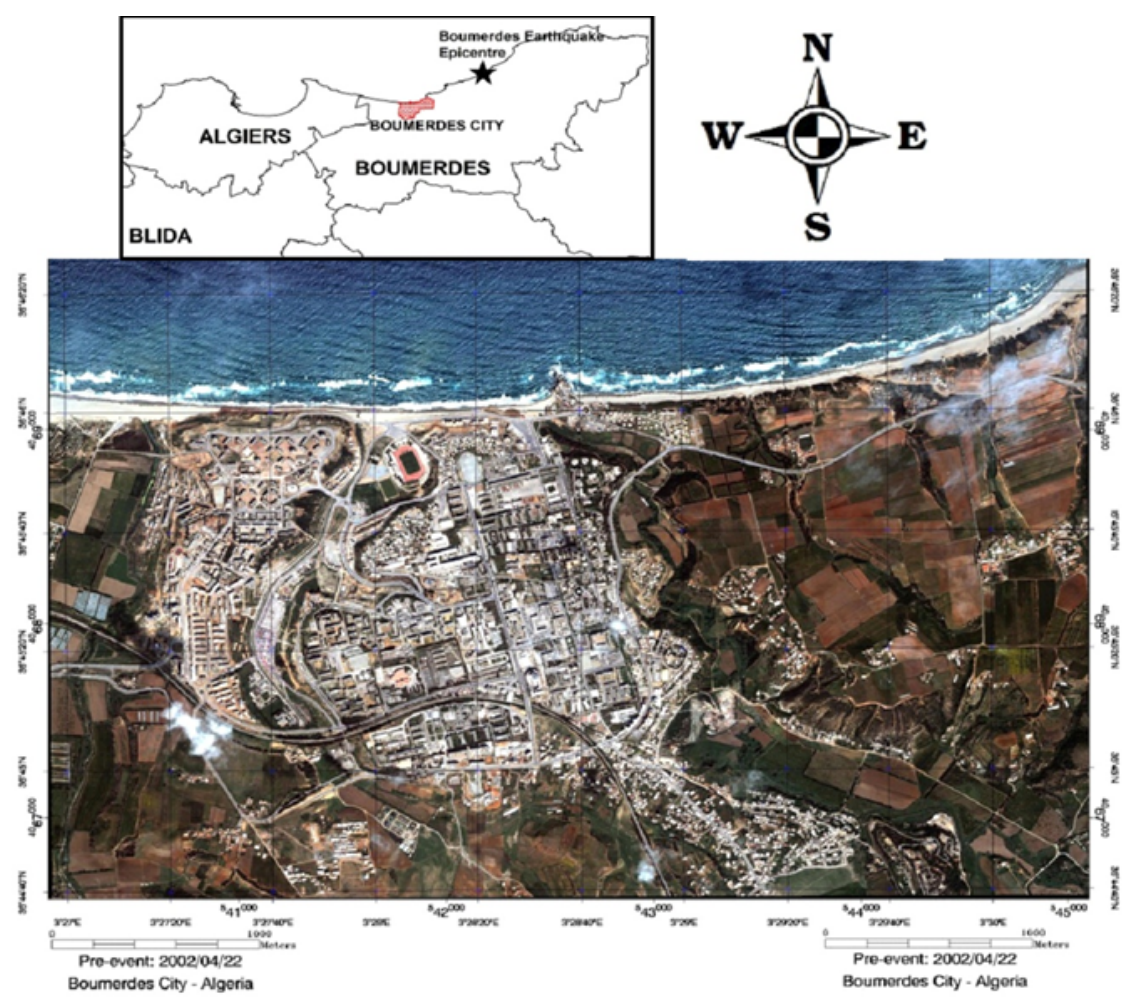

Figure 2: Above: Location of the May 21, 2003 Boumerdès earthquake epicentre (black star). Below: Quick-bird satellite image of Boumerdès city before the earthquake (April 22, 2002) provided by OYO corp. [14].

An interactive data-processing code was developed for this purpose gathering all the methodology steps to analyse the whole data and damage estimation process as illustrated in fig. 1. The building seismic damages in Boumerdès city were estimated using the site elastic response spectrum derived from the accelerometer records obtained during the main shock of the May 21, 2003 earthquake. The results are compared to the real observed damages.

The post-seismic evaluation forms drawn up by experts moved on the affected areas by the earthquake were used on the one hand to consider the damage undergone by constructions and, on the other hand, to make a building classification of Boumerdès city. This evaluation form [15] gathers information of each inspected constructions allowing to consign its damage state according to a 5 damage categories classification $[16,17]$ close to the European Macroseismic Scale, EMS 98 [18, 19]. These damage categories are namely: 1Light green for no damage; 2-Dark green for slight damage; 3-Light orange for moderate damage; 4-Dark orange for important damage and 5-Red for severe damage. 


\subsection{Building characteristics of Boumerdès city: post-quake damage estimation}

The 3663 inspected damaged constructions in Boumerdès city after the earthquake were analysed by the National Centre of Earthquake Engineering [19]. The analysis of the assessed damages (table 3) shows that a significant percentage of masonry buildings have suffered a several (extended and complete) damages, because these constructions are unreinforced masonry built without any design standard. Concerning RC1 buildings, which are prevalent in Boumerdès city and represent the three quarters of the whole assessed buildings, although their half was slightly damaged, they represent the greatest number severely damaged structures (574 units classified between D4 and D5). This is due mainly to the poor quality of concrete and the bad reinforcement of column-beam joints (no stirrups). The more very slightly damaged construction system is RC2 (shear wall), which is used essentially for the buildings belonging to the public inheritance such as the dwelling residences like "Cite 800 logements". This system showed that it is more appropriate in high seismicity zones if it is well designed. The total building classification according to their damage categories is given in table 3.

Table 3: Classification of the observed buildings according to their typology and the relative damages they have suffered.

\begin{tabular}{|c|c|c|c|c|c|c|}
\hline Damage category & D1 & D2 & D3 & D4 & D5 & $\begin{array}{c}\text { Total number of } \\
\text { constructions }\end{array}$ \\
\hline $\begin{array}{c}\text { Number of } \\
\text { constructions }\end{array}$ & 57 & 1766 & 975 & 658 & 207 & \multirow{2}{*}{3663} \\
\cline { 1 - 4 } Percentage (\%) & 1.56 & 48.21 & 26.62 & 17.96 & 5.65 & \\
\hline
\end{tabular}

\subsection{Damage estimation using the developed methodology and comparison to the observed damages}

The Keddara station $(36.65 \mathrm{~N}, 03.41 \mathrm{E})$ located at the south-west of the disaster area (29 km of epicentral distance) has provided the accelerometer record of the main shock which was used to build the elastic response spectrum for this study. The choice to use this record is due to the fact that the station is the closest to the area under study. The $\mathrm{H} / \mathrm{V}$ spectral ratios [20] measurements performed by Meslem et al. [21] show the existence of hard surface layers at Keddara station site. This argues for an absence of amplification.

\subsubsection{Development of the elastic response spectrum $(\zeta=5 \%)$}

The normalized mean elastic response spectrum used in this case (fig. 3) was built from the two horizontal components (E-W and N-S) of the accelerogram recorded at Keddara station. 


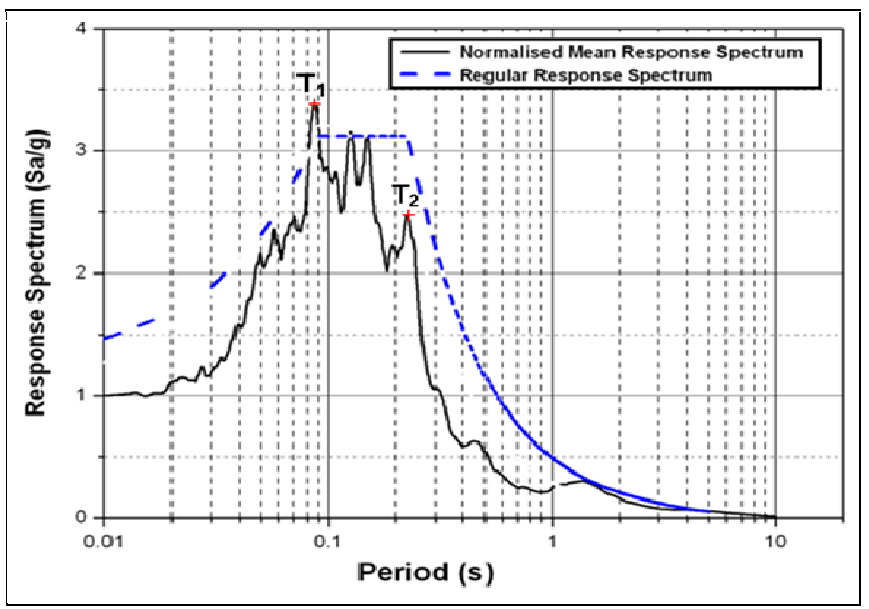

Figure 3: Normalized elastic response spectrum for 5\% damping.

From this response spectrum, we extracted the limit characteristic periods of the constant spectral acceleration branch $T_{1}$ and $T_{2}$, which have as respective values $0.088 \mathrm{~s}$ and $0.227 \mathrm{~s}$. These two periods are used to plot the corresponding normalized elastic spectrum (fig. 3) given by the 1999 Algerian seismic code [22], eqn (1).

$$
\frac{S_{a}}{g}= \begin{cases}1.25\left(1+\frac{T}{T_{1}}\left(2.5 \eta \frac{Q}{R}-1\right)\right) & 0 \leq \mathrm{T} \leq \mathrm{T} 1 \\ 2.5 \eta(1.25 A) \frac{Q}{R} & \mathrm{~T} 1 \leq \mathrm{T} \leq \mathrm{T} 2 \\ 2.5 \eta(1.25 A)\left(\frac{Q}{R}\right)\left(\frac{T_{2}}{T}\right)^{2 / 3} & \mathrm{~T} 2 \leq \mathrm{T} \leq 3.0 \mathrm{~S} \\ 2.5 \eta(1.25 A)\left(\frac{Q}{R}\right)\left(\frac{T_{2}}{3}\right)^{2 / 3}\left(\frac{3}{T}\right)^{5 / 3} & 3.0 \mathrm{~S} \leq \mathrm{T}\end{cases}
$$

where, $A$ : Acceleration coefficient $(\mathrm{A}=1) ; T_{1}, T_{2}$ : Lower and upper limit of the period of the constant spectral acceleration branch and $\eta$ : Damping correction factor given by eqn (2).

$$
\eta=\sqrt{7 /(2+\xi)}
$$

$\xi$ : viscous damping ratio percentage of the structure $(\zeta=5 \%)$. 


\subsubsection{Site acceleration}

The horizontal acceleration on the Boumerdès city was estimated from the 2 horizontal components (EW: $0.34 \mathrm{~g}$ and NS: $0.26 \mathrm{~g}$ ) of the Keddara station record using the Ambraseys et al. [23] attenuation law, given by eqn (3). This attenuation law meets more the characteristics of the Boumerdès earthquake. So the peak ground acceleration value calculated in Boumerdès city is about $0.5 \mathrm{~g}$.

$$
\begin{aligned}
& \log A=a_{1}+a_{2} M_{W}+\left(a_{3}+a_{4} M_{W}\right) \log \sqrt{d^{2}+a_{5}^{2}}+a_{6} S_{S} \\
& +a_{7} S_{A}+a_{8} F_{N}+a_{9} F_{T}+a_{10} F_{0}
\end{aligned}
$$

\subsubsection{Geological and geotechnical context of Boumerdès city}

The geological and geotechnical context of Boumerdès site [24] shows a firm soil type (S2) according to the Algerian seismic code classification $(400 \mathrm{~m} / \mathrm{s} \leq \mathrm{Vs} \leq 800 \mathrm{~m} / \mathrm{s})$.Moreover, the H/V spectral ratios measurements performed on the urban area of Boumerdès city [21, 25, 26] indicate that the shear velocity $(\mathrm{Vs}) \geq 500 \mathrm{~m} / \mathrm{s}$ and show that the site amplification effect can be neglected. This argues that the calculated acceleration value $(\mathrm{A}=0.5 \mathrm{~g})$ is fairly realistic and can be used to build the elastic response spectrum (5\% damping) for the whole Boumerdès city.

\subsubsection{Damage estimation}

The building damage estimation has been done using the methodology developed above. The obtained damages are compared to the real observed damages caused by the May 21st, 2003 earthquake as shown in table 4 and fig. 4 .

\begin{tabular}{|c|c|c|c|c|c|}
\hline Damage probability & PN (D1) & PS (D2) & PM (D3) & PE (D4) & PC (D5) \\
\hline Estimated damages $(\%)$ & 3.3 & 37.6 & 43.2 & 12.3 & 3.6 \\
\hline Observed damages (\%) & 1.6 & 48.0 & 26.7 & 18.0 & 5.7 \\
\hline \multicolumn{6}{|c|}{$\begin{array}{l}\text { PN: No damage probability, PS: Slight damage probability, PM: Moderate damage } \\
\text { probability, PE: important or extensive damage probability and PC: Complete damage } \\
\text { probability. }\end{array}$} \\
\hline
\end{tabular}

Table 4: Global damage probabilities comparison.

\section{Damage discussion}

The comparison of the estimated and observed damages according to the buildings typologies and seismic code periods' shows that they are more or less close in most cases and become almost the same if the damage categories 2 and 3 are merged, as shown in fig. 4. The diagnosis and classification of damaged buildings in these 2 categories (damage D2 and D3) require some qualification and an experience that some inspectors did not have unfortunately. This fact leads to different results between the observed damages and those predicted when making statistics by differentiating these damages, D2 and D3. The difference between the observed and estimated damages is also due to the use of 
American capacity and fragility curves even if a correspondence were made between American and Algerian building typologies. Furthermore, the origin of this difference has also other causes: the elastic response spectrum built from the record signal of Keddara station located at $12 \mathrm{~km}$ from Boumerdès site, , the Poor quality of execution and poor quality of structural material, lack of structural design [3] the aftershocks effect reaching a magnitude $\mathrm{Mw}=5.8$ on 27.05.2003, buildings orientation effect relatively to the fault(directivity effect) (case of Cité Ibn Khaldoun-1200 logements) [27] the presence of many flexible storeys (ground floor) as well as the topographic effect in some places close to the rivers crossing the city (Meslem, 2012). These parameters influenced the effective damages suffered by the buildings in Boumerdès city.

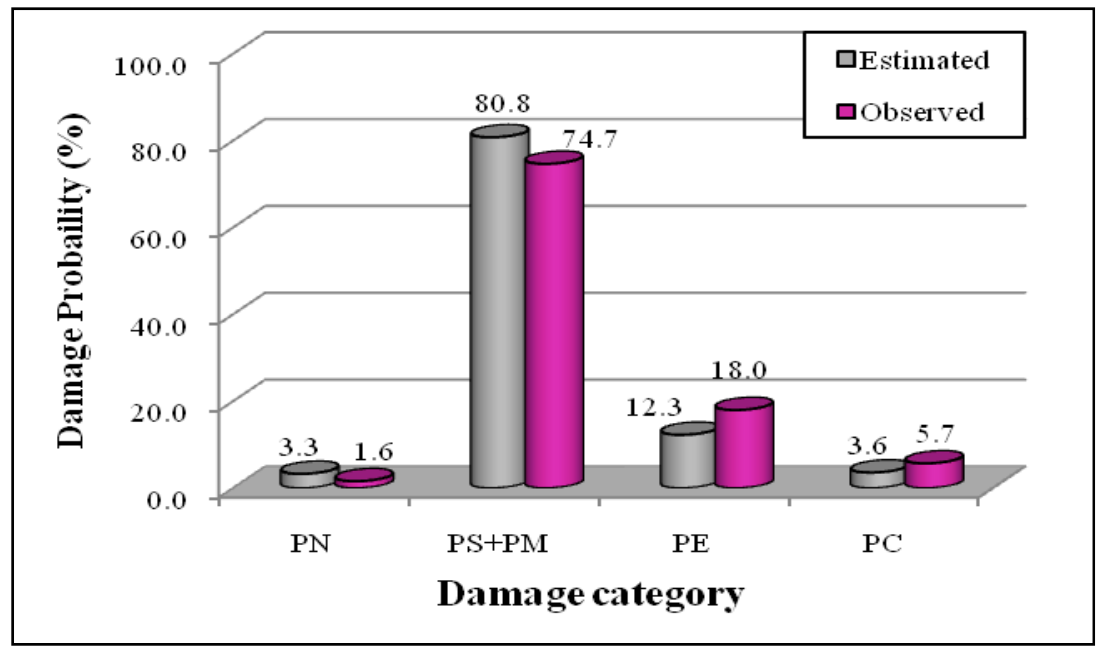

Figure 4: Histogram of the damages for 3,663 buildings in Boumerdès city: observed (CGS in situ evaluation), and estimated.

\section{Conclusion}

In this paper, a seismic damage estimation methodology for Algerian buildings based on HAZUS approach (Hazard-United States) was elaborated whose related capacity and fragility curves were adapted to corresponding typologies for Algerian buildings. A data-processing code was developed for this purpose gathering all the methodology steps. This probabilistic methodology was calibrated with the case of Boumerdès city buildings struck by a destructive moment magnitude 6.8 (Mw) earthquake on May 21st 2003. The seismic damage estimation was performed by representing the Boumerdès earthquake by the elastic response spectrum built from the accelerometer records obtained during the main shock. The results of this scenario in terms of damage were compared with the real observed damages, which were assessed. This comparison showed 
that the theoretical and observed damages are close in the whole of the cases and present a more or less acceptable difference; the results become almost the same if the damage grades 2 and 3 are merged. The origin of the difference between the estimated and observed damages has several causes: adaptation of American capacity and fragility curves to Algerian building typologies, the use of a response spectrum built from the seismic records of free field Keddara station located $12 \mathrm{~km}$ from the Boumerdès city, the quality of the expertises and the errors which could be recorded in the damage classification of constructions, the earthquake characteristics, the location of Boumerdès city in the epicentral zone (strong ground motion zone), the poor quality of execution and structural material, lack of structural design, the aftershocks effect reaching a magnitude $\mathrm{Mw}=5.8$, the buildings orientation effect relatively to the fault (directivity effect), the presence of many flexible stories (Ground floor), as well as the topographic effect in some places close to the rivers crossing the city (Meslem, 2012), etc. These parameters influenced the effective damages suffered by the buildings of the city. Furthermore, the local soil conditions should be known completely in order to provide accurate risk assessment.

The automatic probabilistic processing method by combining its results with GIS tools and GPS location is very helpful for decision making at early days and hours after the occurrence of a disaster as they allow a quick and easy real time survey of the disaster extent.

Finally, we suggest the development of capacity and fragility curves reflecting better the Algerian building context in order to have more precise results with the developed tool.

\section{Acknowledgements}

The data base used in this study was provided by the National Earthquake Engineering Research Centre (CGS). The Quickbird satellite image of Boumerdès city taken the 22/04/2002 is courtesy of OYO Corporation towards CGS in 2006. Part of the work was elaborate within the framework of the cooperation program Tassili Egide PHC (CMEP11MDU847).

\section{References}

[1] Yelles-Chaouche, A. K., Recent seismic activity in northern Algeria. Proc. of the $4^{\text {th }}$ Int. Conf. of Earthquake Engineering and Seismology, Tehran, Islamic Republic of Iran, 2003.

[2] Laouami, N., Slimani, A., Bouhadad, Y., Chatelain, J. L. \& Nour, A., Evidence for fault-related directionality and localized site effects from strong motion recordings of the 2003 Boumerdès (Algeria) earthquake: Consequences on damage distribution and the Algerian seismic code. Soil Dynamics and Earthquake Engineering, 26, pp. 993-1003, 2006.

[3] Belazougui, M., Boumerdès Algeria earthquake of May 21, 2003: Damage analysis and behavior of beam-column reinforced concrete structures. 
Proc. of the $14^{\text {th }}$ World Conf. on Earthquake Engineering, Beijing, China, 2008.

[4] Agrawal, S.K., Microzonation studies as impacted by recent earthquakes in India. Building Material and Technology Promotion Council, New Delhi, pp. 10, 2004.

[5] Charles, S., History of risk model development, Open-source catastrophe risk modeling: How can we do it better? Workshop, California, United States, 2005.

[6] Clark, K., The use of computer modelling in estimating and managing future catastrophe losses. The Geneva Papers on Risk and Insurance, 27(2), p. 15, 2002.

[7] Federal Emergency Management Agency (FEMA), HAZUS99: Earthquake loss estimation methodology, Technical Manual: Washington, DC, USA, 2002.

[8] Mahaney, J. A., Terrence F. P., Bryan E. K. \& Sigmund A. F., The capacity spectrum method for evaluating structural response during the Loma Prieta earthquake. Proc. Of the 1993 United States National Earthquake Conference, Memphis, Tennessee, 2, pp. 501-510, 1993.

[9] Applied Technology Council, ATC-40: Seismic Evaluation and Retrofit of Concrete Buildings, Vol. 1: Redwood City, California, USA, 1996.

[10] Comartin, C., Niewiarowski, R., Freeman, S. A. \& Turner, F., Seismic evaluation and retrofit of concrete buildings: A practical Overview of the ATC 40 Document. Earthquake Spectra, 16, pp. 1-310, 2000.

[11] Chopra, A. K. \& Goël, R. K., Capacity demand diagram methods based on inelastic design spectrum. Earthquake Spectra, 15(4), pp. 637-656, 1999.

[12] Fajfar, P., Capacity spectrum methods based on inelastic demand spectra. Earthquake Engineering and Structural Dynamics, 28, pp. 979-993, 1999.

[13] Boukri, M. \& Bensaïbi, M. (2008). Vulnerability index Algiers masonry buildings. Proc. of the $14^{\text {th }}$ World Conf. on Earthquake Engineering, Beijing, China, 2008.

[14] Bounif, A., Dorbath, C., Ayadi, A., Meghraoui, M., Beldjoudi, H., Laouami, N., Frogneux, M., Slimani, A., Kharroubi, A., Ousadou, F., Chikh, M., Harbi, A., Larbes, S. \& Maouche, S., The 21 May 2003 Zemmouri (Algeria) earthquake $\mathrm{Mw}$ 6.8: Relocation and aftershock sequence analysis. Geophysical Research Letters, 31, pp. 1-4, L19606 doi: 10.1029/2004GL020586, 2004.

[15] Bertero, V. \& Shah H., El-Asnam, Algeria earthquake of October 10, 1980: A reconnaissance and engineering report. Report EERI, January 1983.

[16] Meslem, A. \& Yamazaki, F, Accurate evaluation of building damage in the 2003 Boumerdes, Algeria earthquake from Quickbird satellite images. Journal of Earthquake and Tsunami, 5(1), ed. World Scientific Publishing Company, DOI: 10.1142/S1793431111001029, pp. 1-18, 2011.

[17] Meslem, A., Yamazaki, F., Maruyama, Y., Benouar, D., Kibboua, A. \& Mehani, Y., The effects of building characteristics and site conditions on 
the damage distribution in Boumerdès after the 2003 Algeria earthquak. Earthquake Spectra, 28(1), pp. 185-216, 2012.

[18] Grünthal, G. \& Levret, A., European Macroseismic Scale1998, Cahiers du centre Européen de géodynamique et de seismologie, 19, p. 103, Luxembourg. (in French).

[19] CGS., Statistical study on the damaged buildings following the Boumerdes earthquake of May 21, 2003, National Centre of Earthquake Engineering, 2003.

[20] Farsi, M. N. \& Bard, P. Y., Building Eigen periods Estimation and existing building vulnerability in the area of Grenoble. European journal of environmental and civil engineering, 10 (Y/200Z), 2004. (in French).

[21] Meslem, A., Yamazaki, F., Maruyama, Y., Benouar, D., Laouami, N. \& Benkaci, N., Site-response characteristics evaluated from strong motion records of the 2003 Boumerdès, Algeria earthquake. Earthquake Spectra, 26(3), pp. 803-823, 2010.

[22] Ministry of Housing and Urban Planning., Algerian Seismic Code, RPA99, Algeria, 2000.

[23] Ambraseys, N. N., Douglas, J., Sarma, S. K. \& Smit, P. M., Equations for the estimation of strong ground motions from shallow crustal earthquakes using data from Europe and the Middle East: horizontal peak ground acceleration and spectral acceleration. Bulletin of Earthquake Engineering, Springer, 3, pp. 1-53. DOI 10.1007/s10518-005-0183-0, 2005.

[24] CGS., Seismic microzonation study of urban areas in Boumerdès city. National Earthquake Engineering Research Centre, 2009.

[25] Guillier, B., Machane, D., Oubaiche, E., Chatelain, J. L., Ait-Meziane, Y., Ben-Salem, R. \& Dunand, F. (2004). Preliminary results on the soil fundamental frequencies and amplifications obtained by the H/V study, on the Boumerdès city, Algeria. Memory of the geological service of Algeria, 12, pp. 103-114. (in French)

[26] Hellel, M., Chatelain, J. L., Guillier, B., Machane, D., Ben-Salem, R., Oubaiche, E. \& Haddoum, H. (2010).Heavier Damages without site effects and site Effects with lighter damages: Boumerdès city (Algeria) after the May 2003 Earthquake, 2010. Seismological Research Letter, 81(1), 2010.

[27] Dunand, F., Relevance of the seismic H/V for the dynamic characterization and seismic diagnosis assistance of civil engineering structures. PhD Thesis, University of Joseph Fourrier, Grenoble I, France, (in French). 